\title{
Synergistic effect on Au-Pd bimetallic catalyst during oxidation of benzyl alcohol to sodium benzoate
}

\author{
Zhaoyan Zhang, Ying Wang, Xian Li, Wei-Lin Dai* \\ Department of Chemistry and Shanghai Key Laboratory of Molecular Catalysis and Innovative Materials, Fudan University, Shanghai 200433, China
}

\section{A R T I C L E I N F O}

Article history:

Received 6 May 2014

Accepted 26 May 2014

Published 20 November 2014

\section{Keywords:}

Gold

Palladium

Ceria

Bimetallic catalyst

Benzyl alcohol

Catalytic oxidation

Benzoate

\begin{abstract}
A B S T R A C T
A series of $\mathrm{AuPd} / \mathrm{CeO}_{2}$ bimetallic catalysts with different $\mathrm{Au} / \mathrm{Pd}$ molar ratios were investigated and their catalytic performance in the oxidation of benzyl alcohol to sodium benzoate and benzoic acid under solvent-free conditions was studied. The supported catalysts were characterized by X-ray diffraction, UV-Vis diffuse reflectance spectroscopy, transmission electron microscopy, and X-ray photoelectron spectroscopy. The Au-Pd nanoparticles were successfully deposited onto $\mathrm{CeO}_{2}$ as a homogeneous alloy. The activity of the bimetallic catalysts was superior to that of the corresponding monometallic catalysts. This improvement was attributed to the synergistic effect between $\mathrm{Au}$ and $\mathrm{Pd}$. The catalyst with an $\mathrm{Au} / \mathrm{Pd}$ molar ratio of $3 / 1$ showed the best catalytic performance (the yield of benzoic acid reached 92\%), and it could be easily recovered and reused for more than seven successive reactions without significant loss of activity.
\end{abstract}

(C) 2014, Dalian Institute of Chemical Physics, Chinese Academy of Sciences. Published by Elsevier B.V. All rights reserved.

Goodman and co-workers [19] examined the surface structure of model catalysts, such as $\mathrm{Pd} / \mathrm{Au}(111)$ and $\mathrm{Pd} / \mathrm{Au}(100)$, via the synthesis of vinyl acetate, and demonstrated that $\mathrm{Au}$ on $\mathrm{Pd}$ resulted in catalysts with greatly improved activity and selectivity. Keane and co-workers [20] examined a significant increase in activity of $\mathrm{AuPd} / \mathrm{Al}_{2} \mathrm{O}_{3}$ when compared with $\mathrm{Au} / \mathrm{Al}_{2} \mathrm{O}_{3}$ towards the hydrogenation of $p$-chloronitrobenzene. Hao's group [21] demonstrated that the addition of Pd to Au/SBA-15 catalysts could decrease the size of the gold nanoparticles, resulting in higher activity towards the selective aerobic oxidation of benzyl alcohol. Additionally, Huang's group [22] has reported the effect of the $\mathrm{Au} / \mathrm{Pd}$ molar ratio of bimetallic $\mathrm{AuPd} / \mathrm{MgO}$ on the liquid phase oxidation of benzyl alcohol to benzaldehyde. Regardless, to date, the application of $\mathrm{Au}-\mathrm{Pd}$ bimetallic catalysts in the oxidation of benzyl alcohol to sodium

\footnotetext{
*Corresponding author. Tel: +86-21-55664678; Fax: +86-21-55665701; E-mail: wldai@fudan.edu.cn This work was supported by the National Basic Research Program of China (973 Program, 2012CB224804), the National Natural Science Foundation of China (21373054, 21173052), and the Natural Science Foundation of Shanghai Science and Technology Committee (08DZ2270500).
} DOI: 10.1016/S1872-2067(14)60159-5 | http://www.sciencedirect.com/science/journal/18722067 | Chin. J. Catal., Vol. 35, No. 11, November 2014 
benzoate and benzoic acid has rarely been reported.

Cerium oxide $\left(\mathrm{CeO}_{2}\right)$ is an effective catalyst employed in various organic reactions such as transamidation of amides [23], selective synthesis of esters from nitriles and alcohols [24], preparation of organic carbamates [25], synthesis of $\mathrm{N}$-alkyl amides [26], and reduction of $\mathrm{NO}_{x}$ [27]. Because $\mathrm{CeO}_{2}$ has acid-base and redox properties that are expected to facilitate and promote catalysis performance $[28,29], \mathrm{CeO}_{2}$ has been used to support $\mathrm{Au}$ [30,31], $\mathrm{Cu}[32], \mathrm{Ru}[33,34], \mathrm{Pt}$ [35], and Pd [36] to catalyze diverse inorganic and organic reactions. Moreover, $\mathrm{Au} / \mathrm{CeO}_{2}$ catalyst has been reported to exhibit better catalytic performance than $\mathrm{Au} / \mathrm{TiO}_{2}$ and $\mathrm{Au} / \mathrm{Fe}_{2} \mathrm{O}_{3}$ towards $\mathrm{CO}$ oxidation [30]. Therefore, $\mathrm{CeO}_{2}$ is considered a promising support candidate to load gold and other noble metals.

Sodium benzoate and benzoic acid are important commodity chemicals with wide use as food additives, preservatives, spices, plasticizers, and mordants. As reported, sodium benzoate and benzoic acid can be prepared upon oxidation of benzyl alcohol in a one-pot solvent-free synthesis method that is environmentally friendly, non-toxic, and energy-efficient [37]. A novel efficient $\mathrm{AuAg} / \mathrm{TiO}_{2}$ bimetallic catalyst with a high stability was employed in this reaction. The catalyst that was prepared with an $\mathrm{Au} / \mathrm{Ag}$ molar ratio of $1 / 3$ produced the best catalytic performance. To further improve the catalytic activity and evaluate the synergistic effect between $\mathrm{Au}$ and $\mathrm{Pd}$, herein, we report the preparation of $\mathrm{AuPd} / \mathrm{CeO}_{2}$ bimetallic catalysts and investigate their catalytic properties towards the oxidation of benzyl alcohol to sodium benzoate and benzoic acid. A series of $\mathrm{AuPd} / \mathrm{CeO}_{2}$ catalysts with different $\mathrm{Au} / \mathrm{Pd}$ molar ratios were obtained and structurally characterized by UV-Vis diffuse reflectance spectroscopy (DRS), transmission electron microscopy (TEM), and X-ray photoelectron spectroscopy (XPS). It was found that the Au-Pd nanoparticles were mainly present as homogeneous alloys and the catalyst prepared with an $\mathrm{Au} / \mathrm{Pd}$ ratio of 3/1 displayed optimum catalytic performance.

\section{Experimental}

\subsection{Catalyst preparation}

$\mathrm{Au}-\mathrm{Pd}$ bimetallic catalyst with an $\mathrm{Au} / \mathrm{Pd}$ molar ratio of $1 / 1$ was loaded on different supports, and the synthesis process was as follows. First, Au/support catalyst was prepared by a deposition-precipitation (DP) method using urea as precipitation agent. Then, $1.0 \mathrm{~g}$ of support $\left(\mathrm{TiO}_{2}, \mathrm{MnO}_{2}, \mathrm{SnO}_{2}, \mathrm{ZnO}\right.$, or $\mathrm{CeO}_{2}$ ), $9 \mathrm{~mL}$ of aqueous $\mathrm{HAuCl}_{4}$ solution (24.3 mmol/L), and 2.6 $\mathrm{g}$ of urea were added to $80 \mathrm{~mL}$ of $\mathrm{H}_{2} \mathrm{O}$ with continuous stirring. The mixture was stirred for $2 \mathrm{~h}$ at $353 \mathrm{~K}$, during which the $\mathrm{pH}$ value was gradually increased from 3.0 to 8.0. The as-received precipitate was collected by filtration, washed three times with deionized water, and dried overnight at $373 \mathrm{~K}$, followed by calcination for $4 \mathrm{~h}$ at $573 \mathrm{~K}$. Then, the Pd species were loaded on the as-synthesized precursor mentioned above using an impregnation (IM) method. Typically, $1.0 \mathrm{~g}$ of the as-synthesized precursor was added to $7.2 \mathrm{~mL}$ of aqueous $\mathrm{PdCl}_{2}$ solution ( $56.3 \mathrm{mmol} / \mathrm{L}$ ) and mixed with $40 \mathrm{~mL}$ of $\mathrm{H}_{2} \mathrm{O}$. The resulting slurry was vigorously stirred at $353 \mathrm{~K}$ until complete evapora- tion of water, and the solid material was dried at $373 \mathrm{~K}$, followed by calcination for $4 \mathrm{~h}$ at $673 \mathrm{~K}$. The as-synthesized catalyst is denoted as AuPd/MO, where MO represents the support (i.e., $\mathrm{TiO}_{2}, \mathrm{MnO}_{2}, \mathrm{SnO}_{2}, \mathrm{ZnO}$, or $\mathrm{CeO}_{2}$ ). It should be noted that the total metal loading and the $\mathrm{Au} / \mathrm{Pd}$ molar ratio of all AuPd/MO catalysts were controlled at $8 \mathrm{wt} \%$ and $1: 1$, respectively.

Monometallic $\mathrm{Au} / \mathrm{CeO}_{2}$ catalyst was prepared by DP using urea as precipitation agent. First, $1.0 \mathrm{~g}$ of $\mathrm{CeO}_{2}$ (Aldrich), $18 \mathrm{~mL}$ of aqueous $\mathrm{HAuCl}_{4}$ solution (24.3 mmol/L), and $5.2 \mathrm{~g}$ of urea were added to $80 \mathrm{~mL}$ of $\mathrm{H}_{2} \mathrm{O}$ with continuous stirring. The mixture was stirred for $2 \mathrm{~h}$ at $353 \mathrm{~K}$, during which the $\mathrm{pH}$ value was gradually increased from 3.0 to 8.0. The as-received precipitate was collected by filtration, washed three times with deionized water, and dried overnight at $373 \mathrm{~K}$, and calcined for $4 \mathrm{~h}$ at $573 \mathrm{~K}$.

Monometallic $\mathrm{Pd} / \mathrm{CeO}_{2}$ catalyst was prepared by IM. First, $1.0 \mathrm{~g}$ of $\mathrm{CeO}_{2}$ was added to $14.5 \mathrm{~mL}$ of aqueous $\mathrm{PdCl}_{2}$ solution (56.3 mmol/L) and mixed with $80 \mathrm{~mL}$ of $\mathrm{H}_{2} \mathrm{O}$. The resulting slurry was vigorously stirred at $353 \mathrm{~K}$ until complete evaporation of water, and the solid material was dried at $373 \mathrm{~K}$, and then calcined for $4 \mathrm{~h}$ at $673 \mathrm{~K}$.

The synthesis process of the bimetallic catalysts with different $\mathrm{Au} / \mathrm{Pd}$ molar ratios was as follows. First, $\mathrm{Au} / \mathrm{CeO}_{2}$ was prepared by DP (similarly to the monometallic $\mathrm{Au} / \mathrm{CeO}_{2}$ ). Then, $\mathrm{AuPd} / \mathrm{CeO}_{2}$ was prepared by IM (similarly to the monometallic $\mathrm{Pd} / \mathrm{CeO}_{2}$ ), with $\mathrm{Au} / \mathrm{CeO}_{2}$ as the support. The total metal loading was controlled at $8 \mathrm{wt} \%$. The catalysts prepared at varying $\mathrm{Au} / \mathrm{Pd}$ molar ratios of $3 / 1,2 / 2$, and $1 / 3$ are denoted as $3 \mathrm{Au} 1 \mathrm{Pd} / \mathrm{CeO}_{2}, 2 \mathrm{Au} 2 \mathrm{Pd} / \mathrm{CeO}_{2}$, and $1 \mathrm{Au} 3 \mathrm{Pd} / \mathrm{CeO}_{2}$, respectively.

\subsection{Catalyst characterization}

The specific surface area of the samples was determined by nitrogen adsorption at $77 \mathrm{~K}$ (Micromeritics TriStar ASAP 3000) using the Brunauer-Emmett-Teller (BET) method. The Au and Pd loadings were determined by the inductively coupled plasma atomic emission spectroscopy (ICP-AES, Thermo E. IRIS). The XRD patterns were recorded on a Bruker D8 advance diffractometer with $\mathrm{Cu} K_{\alpha}$ radiation $(\lambda=0.154 \mathrm{~nm})$, operating at $40 \mathrm{~mA}$ and $40 \mathrm{kV}$. The XPS spectra were recorded under ultra-high vacuum $\left(<10^{-6} \mathrm{~Pa}\right)$ at a pass energy of $93.90 \mathrm{eV}$ on a Perkin Elmer PHI 5000C ESCA system equipped with a dual X-ray source using $\mathrm{Mg} K_{\alpha}(1253.6 \mathrm{eV})$ anode and a hemispherical energy analyzer. All binding energy was calibrated using contaminant carbon ( $\mathrm{C} 1 s=284.6 \mathrm{eV}$ ) as a reference. The TEM images were obtained on a JOEL JEM 2010 transmission electron microscope. The UV-Vis DRS spectra were collected using a Shimadzu UV-2450 spectrophotometer operating in the scanning range of 200-800 nm using $\mathrm{BaSO}_{4}$ as background.

\subsection{Activity test}

All the experiments were carried out in a magnetically stirred glass flask under reflux; a mercury thermometer was used to monitor the reaction temperature that was maintained at $453 \mathrm{~K}$ using an oil bath. A predetermined quantity of benzyl alcohol (1.08 g) was introduced into the reactor, and then 
$\mathrm{AuPd} / \mathrm{CeO}_{2}$ (0.05 g) and $\mathrm{NaOH}$ (0.5 g) were added. The temperature-controlled reaction mixture was stirred at $800 \mathrm{rpm}$ for $8 \mathrm{~h}$. Following addition of $12 \mathrm{~mL}$ of $\mathrm{H}_{2} \mathrm{O}$, the reaction mixture was centrifuged to remove the catalyst. The filtrate was evaporated and crystallized to obtain sodium benzoate (white solid) with purity of $>99 \%$.

The as-obtained filtrate was acidified with aqueous $\mathrm{HCl}$ solution until a $\mathrm{pH}$ value of 2.0 was attained. The resulting mixture was filtered, and benzoic acid (white solid) was obtained with purity of $>99 \%$. Finally, the white solid was dried and weighed. Yield (benzyl acid $)=\left(n_{\text {benzyl acid }} / n_{\text {benzyl alcohol }}\right) \times 100 \%$. For the recycling test, the spent catalyst was washed with dilute aqueous $\mathrm{HCl}$ solution thrice and then calcined at $573 \mathrm{~K}$ for $4 \mathrm{~h}$.

\section{Results and discussion}

\subsection{Effect of support on the performance of Au-Pd bimetallic catalysts}

The catalytic performance is greatly influenced by the support. The specific surface areas, surface acid-base properties, specific surface functional groups, and metal-support interactions or other structural features would affect the catalytic reaction process. In our study, oxidation of benzyl alcohol to sodium benzoate and benzoic acid was examined in the presence of a series of AuPd/MO catalysts (prepared on various supports, MO) to investigate the influence of the support on the catalyst performance. The results are shown in Fig. 1. The $\mathrm{MnO}_{2}$ - and $\mathrm{SnO}_{2}$-supported $\mathrm{Au}$-Pd bimetallic catalysts that featured higher amounts of basic sites displayed the lowest catalytic performance. The low catalytic properties could be attributed to the excessive amounts of basic sites and the small specific surface areas [38]. Both the $\mathrm{TiO}_{2}$ - and $\mathrm{ZnO}$-supported $\mathrm{Au}-\mathrm{Pd}$ bimetallic catalysts exhibited higher catalytic properties when compared with the $\mathrm{MnO}_{2}$ - and $\mathrm{SnO}_{2}$-supported $\mathrm{Au}-\mathrm{Pd}$ bimetallic catalysts. $\mathrm{AuAg} / \mathrm{TiO}_{2}$ catalysts have been reported as a promising catalyst for the transformation of benzyl alcohol to sodium benzoate [39]. However, the yield of sodium benzoate was only about $78 \%$, and the $\mathrm{TiO}_{2}$ loaded with the $\mathrm{Au}-\mathrm{Pd}$ bimetallic catalysts was prone to aggregation in the absence of a

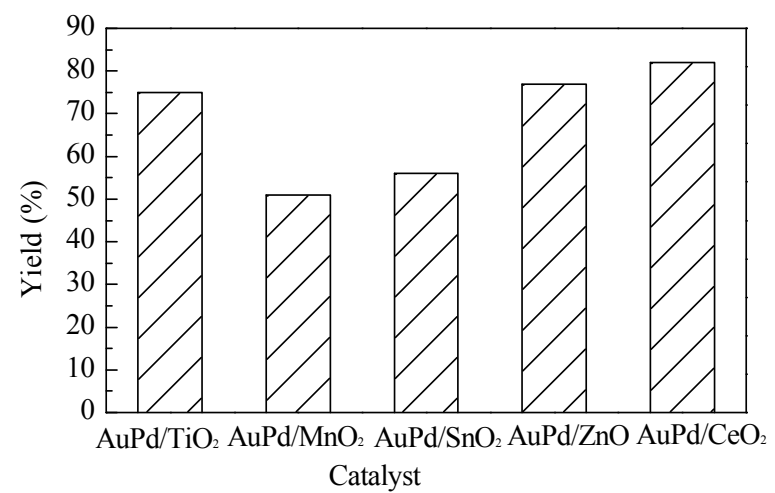

Fig. 1. Catalytic performance of the Au-Pd bimetallic catalysts loaded on different supports, as measured by the benzoic acid yield. Reaction conditions: temperature $453 \mathrm{~K}$, reaction time $8 \mathrm{~h}, 1.08 \mathrm{~g}$ benzyl alcohol, $0.5 \mathrm{~g} \mathrm{NaOH}$, and $0.05 \mathrm{~g}$ catalyst. protective agent. The catalytic performance of $\mathrm{AuPd} / \mathrm{ZnO}$ catalyst is lower when compared with that of $\mathrm{AuPd} / \mathrm{CeO}_{2}$, and the poor benzoic acid yield is attributed to the low amounts of acid sites of the $\mathrm{ZnO}$ support [40]. In contrast, the $\mathrm{CeO}_{2}$-supported $\mathrm{Au}-\mathrm{Pd}$ bimetallic catalysts displayed higher amounts of acid sites and larger specific surface areas. Moreover, it is known that the strong metal-support interaction (SMSI) effect, first reported by Tauster et al. in 1978 [41], greatly enhances the interactions between the $\mathrm{Au}-\mathrm{Pd}$ bimetallic species and $\mathrm{CeO}_{2}$ support that subsequently would lead to extended stability of the $\mathrm{AuPd} / \mathrm{CeO}_{2}$ catalysts. Thus, the $\mathrm{CeO}_{2}$ support was chosen in the subsequent studies.

\subsection{Catalyst characterization}

\subsection{1. $\quad \mathrm{N}_{2}$ adsorption and ICP-AES analyses}

The physicochemical properties of the $\mathrm{CeO}_{2}$-supported $\mathrm{Au}-\mathrm{Pd}$ bimetallic catalysts with varying $\mathrm{Au} / \mathrm{Pd}$ molar ratios are listed in Table 1. There were no obvious differences in the pore volume and average pore size, indicating that the introduction of the metal species on the support did not considerably influence the catalyst structure. A slight increase in the BET specific surface areas was observed following loading of the bimetallic species. Based on the ICP-AES analysis, the actual loading of $\mathrm{Au}$ or Pd was comparable with the nominal amount, indicative of the successful deposition of $\mathrm{Au}$ and $\mathrm{Pd}$ on the $\mathrm{CeO}_{2}$ support.

\subsubsection{XRD analysis}

The XRD patterns of the monometallic and bimetallic catalysts are shown in Fig. 2. The $\mathrm{CeO}_{2}$ support is well crystallized showing characteristic diffractogram of fluorite. The $f c c$ peaks of $\mathrm{Au}$ were observed at $2 \theta=38.2^{\circ}$, and the intensity of the $\mathrm{Au}$ diffraction peak decreased with increasing amounts of $\mathrm{Pd}$. The weak broad peak at $2 \theta=40.1^{\circ}$, which is characteristic of metallic Pd species, suggests the existence of Pd in the as-prepared $\mathrm{Au}-\mathrm{Pd}$ bimetallic catalysts (Fig. 2(2)-(5)). A right shift in the $\mathrm{Au}$ peaks from $2 \theta=38.2^{\circ}$ to $2 \theta=38.9^{\circ}$ was observed, and all the peaks were located between the peaks corresponding to the (111) plane of metallic gold and (111) plane of metallic palladium, suggesting the formation of Au-Pd alloy [42]. Monometallic $\mathrm{Pd} / \mathrm{CeO}_{2}$ (Fig. 2(5)) displayed a diffraction peak corresponding to PdO species formed upon oxidation of Pd during the calcination process. The broad and weak diffraction peak suggests that the size of PdO is very small. Based on the XRD results, both the PdO nanocrystallites and metallic Pd species

Table 1

Physicochemical properties of $\mathrm{AuPd} / \mathrm{CeO}_{2}$ catalysts with different $\mathrm{Au} / \mathrm{Pd}$ molar ratios.

\begin{tabular}{lcccc}
\hline \multirow{2}{*}{ Catalyst } & \multirow{2}{*}{$\begin{array}{c}A_{\text {BET }} \\
\left(\mathrm{m}^{2} / \mathrm{g}\right)\end{array}$} & \multicolumn{2}{c}{ Content $^{\mathrm{a}}(\mathrm{wt} \%)$} & \multirow{2}{*}{$\begin{array}{c}\text { Au particle size } \\
\text { b }\end{array}$} \\
\cline { 3 - 4 } & 67.1 & 7.9 & 0 & 4.5 \\
$\mathrm{Au} / \mathrm{CeO}_{2}$ & 70.3 & 5.7 & 1.5 & 4.8 \\
$3 \mathrm{Au} 1 \mathrm{Pd} / \mathrm{CeO}_{2}$ & 72.6 & 3.8 & 3.4 & 5.4 \\
$2 \mathrm{Au} 2 \mathrm{Pd} / \mathrm{CeO}_{2}$ & 71.6 & 1.9 & 5.5 & 5.7 \\
$1 \mathrm{Au} 3 \mathrm{Pd} / \mathrm{CeO}_{2}$ & 71.0 & 0 & 7.7 & 5.2 \\
$\mathrm{Pd} / \mathrm{CeO}_{2}$ & 71.0 & & &
\end{tabular}

${ }^{a}$ Determined by ICP.

bThe calculated Au particle size was based on the analysis of more than 200 particles from TEM images. 


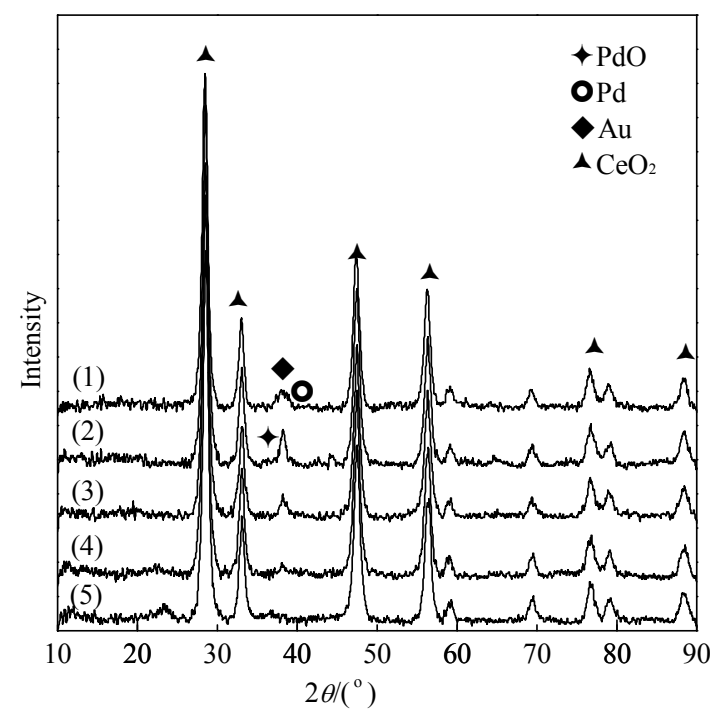

Fig. 2. XRD patterns of $\mathrm{AuPd} / \mathrm{CeO}_{2}$ catalysts with different $\mathrm{Au} / \mathrm{Pd}$ molar ratios. (1) $\mathrm{Au} / \mathrm{CeO}_{2}$; (2) 3/1; (3) 2/2; (4) 1/3; (5) $\mathrm{Pd} / \mathrm{CeO}_{2}$.

were present in the bimetallic catalysts.

\subsubsection{UV-Vis DRS study}

Figure 3 shows the UV-Vis DRS spectra of the catalysts with different $\mathrm{Au} / \mathrm{Pd}$ molar ratios. A weak absorption band at $\sim 570$ $\mathrm{nm}$ was observed for monometallic $\mathrm{Au} / \mathrm{CeO}_{2}$ catalyst that is due to the surface plasma resonance of the metallic Au particles [43]. As observed, the peak is red-shifted with increasing amounts of Pd, owing to the inter-band transitions of the bimetallic alloy nanoparticles [44-47]. Thus, this finding confirms the formation of an Au-Pd alloy rather than individual and distinct monometallic Au and Pd particles.

\subsubsection{TEM results}

Figure 4 shows the TEM images and particle size distributions of the $\mathrm{AuPd} / \mathrm{CeO}_{2}$ catalysts with different $\mathrm{Au} / \mathrm{Pd}$ molar ratios. The metallic particles displayed a narrow size distribu-

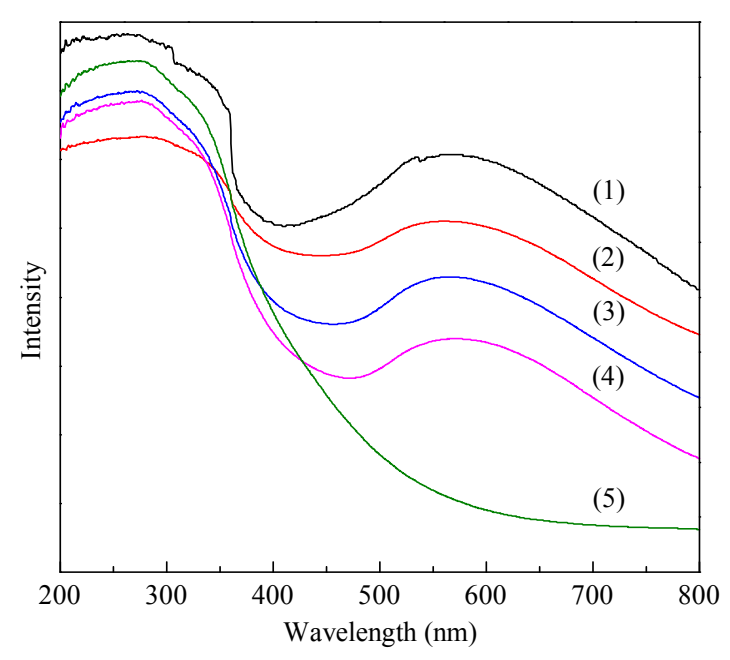

Fig. 3. UV-Vis DRS spectra of $\mathrm{AuPd} / \mathrm{CeO}_{2}$ catalysts with different $\mathrm{Au} / \mathrm{Pd}$ molar ratios. (1) $\mathrm{Au} / \mathrm{CeO}_{2}$; (2) 3/1; (3) 2/2; (4) 1/3; (5) $\mathrm{Pd} / \mathrm{CeO}_{2}$.

tion and were well dispersed on the surface of the support. The average particle sizes of the monometallic $\mathrm{Au} / \mathrm{CeO}_{2}$ and $\mathrm{Pd} / \mathrm{CeO}_{2}$ catalysts are 4.5 and $5.2 \mathrm{~nm}$, respectively. The morphology of metallic particles was greatly influenced by the addition of the second metal. Compared with the monometallic $\mathrm{Au}$ particle, the bimetallic particle size tends to be larger with increasing Pd contents. The mean particle size of the catalysts with $\mathrm{Au} / \mathrm{Pd}$ ratios of $3 / 1,2 / 2$, and $1 / 3$ is $4.8,5.4$, and $5.7 \mathrm{~nm}$, respectively. The $3 \mathrm{Au} 1 \mathrm{Pd} / \mathrm{CeO}_{2}$ catalyst featured the smallest average particle size that is expected to improve the catalytic performance.

\subsubsection{XPS analysis}

The XPS spectra of the catalysts with different $\mathrm{Au} / \mathrm{Pd}$ molar ratios are shown in Fig. 5. The corresponding deconvoluted $\mathrm{Au}$ $4 f$ and Pd $3 d$ XPS spectra are shown in Figs. 6 and 7. The calculated surface contents of $\mathrm{Au}$ and Pd species based on the XPS results are listed in Tables 2 and 3. As observed, the content of
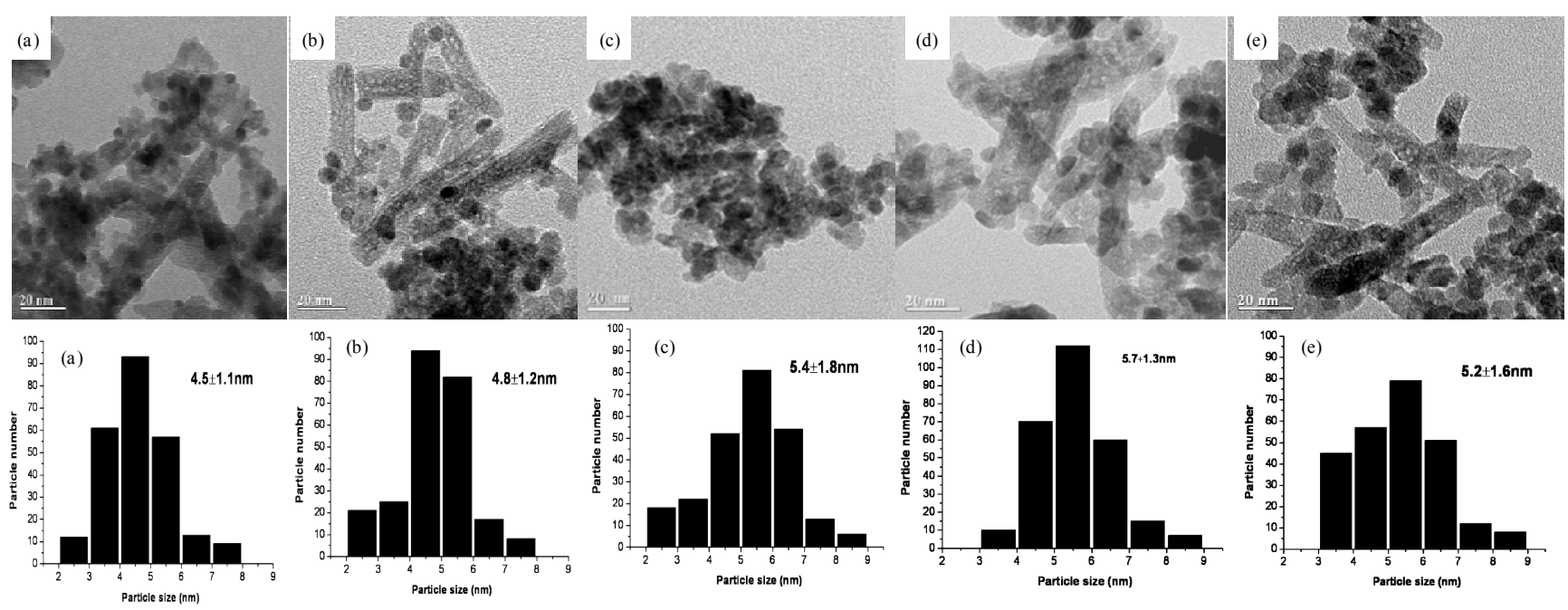

Fig. 4. TEM images and particle size distributions of $\mathrm{AuPd} / \mathrm{CeO}_{2}$ catalysts with different $\mathrm{Au} / \mathrm{Pd}$ molar ratios. (a) $\mathrm{Au} / \mathrm{CeO}$; (b) 3/1; (c) 2/2; (d) 1/3; (e) $\mathrm{Pd} / \mathrm{CeO}_{2}$. 

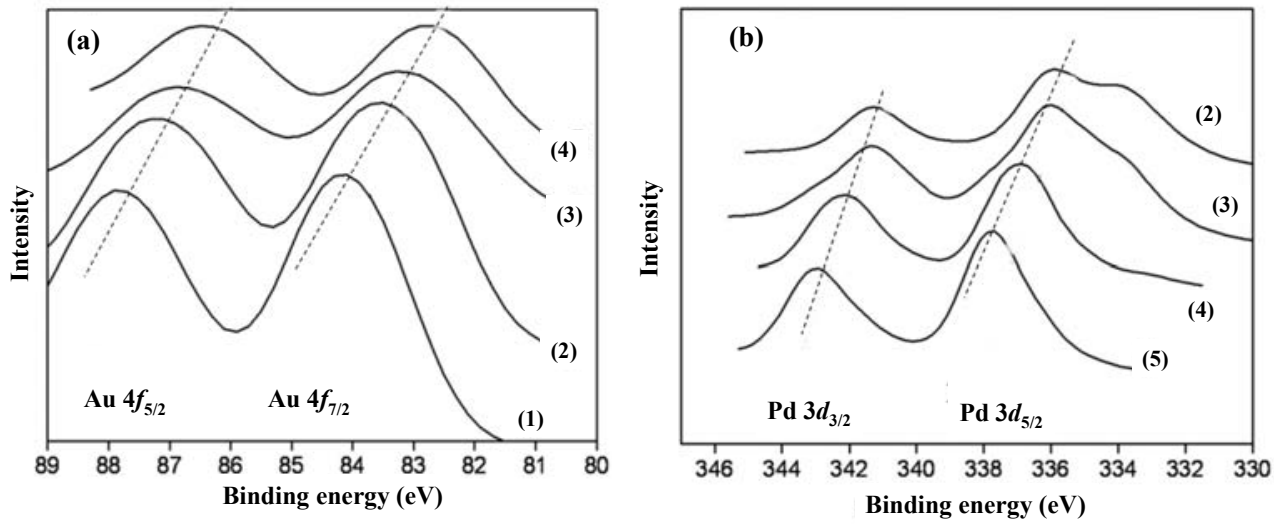

Fig. 5. (a) $\mathrm{Au} 4 f$ and (b) Pd $3 d$ XPS spectra of $\mathrm{AuPd} / \mathrm{CeO}_{2}$ catalysts with different $\mathrm{Au} / \mathrm{Pd}$ molar ratios. (1) $\mathrm{Au} / \mathrm{CeO}_{2}$; (2) 3/1; (3) 2/2; (4) 1/3; (5) $\mathrm{Pd} / \mathrm{CeO}_{2}$.

$\mathrm{Au}$ and Pd on the surface of the support is higher than that in bulk (Table 2). However, the surface $\mathrm{Au} / \mathrm{Pd}$ ratio is slightly higher than the nominal $\mathrm{Au} / \mathrm{Pd}$ value, implying an enrichment of $\mathrm{Au}$ species on the surface of the $\mathrm{CeO}_{2}$ support. The same phenomenon was also reported and discussed in the studies on model bimetallic Pd-Au catalysts [48,49].

Because the peaks corresponding to $\mathrm{Au}^{0} 4 d_{5 / 2}(333.8 \mathrm{eV})$ and $\mathrm{Pd}^{0} 3 d_{5 / 2}(334.0 \mathrm{eV})$, and $\mathrm{Au}^{0} 4 f_{5 / 2}(87.7 \mathrm{eV})$ and $\mathrm{Pd}^{0} 4 s$ $(88.2 \mathrm{eV})$ overlap $[3,50]$, the chemical states of the Au and Pd species were examined using the $\mathrm{Au} 4 f_{7 / 2}$ and $\mathrm{Pd} 3 d_{3 / 2}$ peaks. Monometallic $\mathrm{Au} / \mathrm{CeO}_{2}$ catalyst featured an $\mathrm{Au} 4 f_{7 / 2}$ peak at $83.7 \mathrm{eV}$, corresponding to $\mathrm{Au}^{\delta+}$ and $\mathrm{Au}^{0}$ species. Increasing the $\mathrm{Pd}$ content resulted in a negative shift of the $\mathrm{Au} 4 f_{7 / 2}$ peak (Fig. 5(a)) and the surface species of $\mathrm{Au}$ changed to $\mathrm{Au}^{0}$ and $\mathrm{Au}^{\delta-}$, regardless of the studied bimetallic catalyst. Moreover, the amount of $\mathrm{Au}^{\delta-}$ increased with increasing Pd amounts (Fig. 5), indicating the transfer of electrons from Pd to $\mathrm{Au}$.

Monometallic $\mathrm{Pd} / \mathrm{CeO}_{2}$ catalyst consisted of $\mathrm{Pd}^{0}, \mathrm{Pd}^{2+}$, and $\mathrm{Pd}^{4+}$ species on the surface of the support. The appearance of $\mathrm{Pd}^{\delta+}$ species is due to the oxidation of partial $\mathrm{Pd}$ during the calcination process. When the amount of $\mathrm{Au}$ increased, the Pd $3 d_{3 / 2}$ peaks of the bimetallic catalysts shifted to lower binding energy when compared with that in $\mathrm{Pd} / \mathrm{CeO}_{2}$ (Fig. 5(b)). The $\mathrm{Au} 4 f_{7 / 2}$ and $\mathrm{Pd} 3 d_{3 / 2}$ peak shift to lower binding energy demonstrates the net charge flow between $\mathrm{Au}$ and Pd [51-54]. With increasing $\mathrm{Au}$ contents, the $\mathrm{Pd}^{\delta+}$ species in the bimetallic catalysts were converted into the metallic state (Table 3). Thus, it is believed that Au tends to accept electrons, whereas Pd has
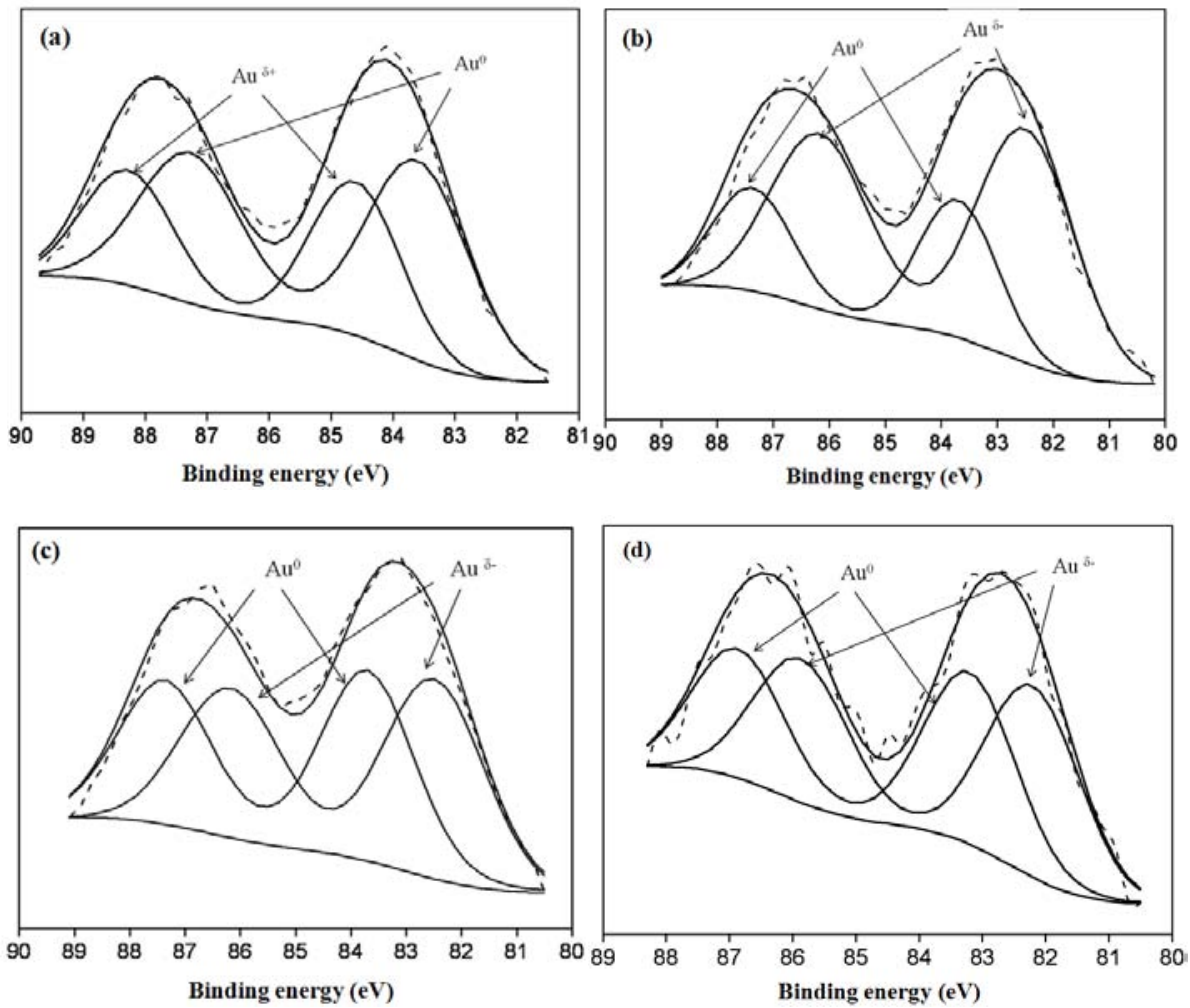

Fig. 6. $\mathrm{Au} 4 f \mathrm{XPS}$ spectra of $\mathrm{AuPd} / \mathrm{CeO}_{2}$ catalysts with different $\mathrm{Au} / \mathrm{Pd}$ molar ratios. (a) $\mathrm{Au} / \mathrm{CeO}_{2}$; (b) 3/1; (c) 2/2; (d) $1 / 3$. 

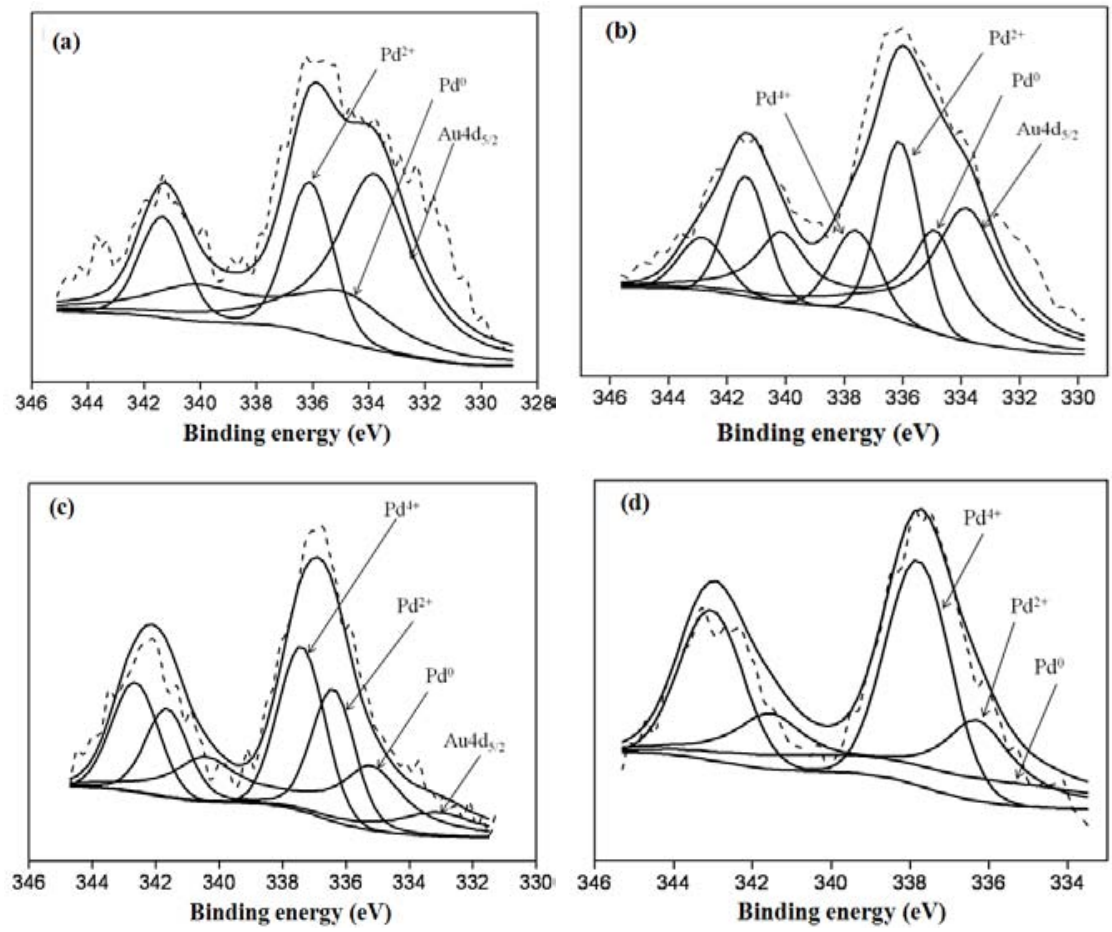

Fig. 7. $\mathrm{Pd} 3 d \mathrm{XPS}$ spectra of $\mathrm{AuPd} / \mathrm{CeO}_{2}$ catalysts with different $\mathrm{Au} / \mathrm{Pd}$ molar ratios. (a) $3 / 1$; (b) 2/2; (c) $1 / 3$; (d) $\mathrm{Pd} / \mathrm{CeO}_{2}$.

the tendency to lose electrons because of the presence of a synergistic effect between $\mathrm{Au}$ and Pd, alluding to the formation of an Au-Pd alloy.

\subsection{Catalytic oxidation of benzyl alcohol}

The catalytic oxidation of benzyl alcohol to sodium benzoate under solvent-free conditions in the presence of $\mathrm{NaOH}$ is known as the Cannizzaro reaction. Benzyl alcohol was oxidized to benzoic aldehyde that instantaneously transformed into sodium benzoate in an alkaline environment.

Table 4 shows the catalytic results using monometallic and bimetallic catalysts towards the oxidation of benzyl alcohol to

Table 2

Surface and bulk compositions of $\mathrm{AuPd} / \mathrm{CeO}_{2}$ catalysts obtained from XPS and ICP-AES, respectively.

\begin{tabular}{|c|c|c|c|c|}
\hline \multirow{2}{*}{ Catalyst } & \multicolumn{2}{|c|}{ Surface content (\%) } & \multicolumn{2}{|c|}{$\mathrm{Au} / \mathrm{Pd}$ molar ratio } \\
\hline & $\mathrm{Au}$ & $\mathrm{Pd}$ & Surface & Bulk \\
\hline $\mathrm{Au} / \mathrm{CeO}_{2}$ & 9.3 & - & - & - \\
\hline $3 \mathrm{Au} 1 \mathrm{Pd} / \mathrm{CeO}_{2}$ & 8.6 & 2.7 & 3.2 & 2.0 \\
\hline $2 \mathrm{Au} 2 \mathrm{Pd} / \mathrm{CeO}_{2}$ & 4.0 & 3.6 & 1.1 & 0.6 \\
\hline $1 \mathrm{Au} 3 \mathrm{Pd} / \mathrm{CeO}_{2}$ & 3.2 & 6.4 & 0.5 & 0.2 \\
\hline $\mathrm{Pd} / \mathrm{CeO}_{2}$ & 一 & 8.1 & 一 & - \\
\hline
\end{tabular}

Table 3

Content of $\mathrm{Au}$ and $\mathrm{Pd}$ surface species of $\mathrm{AuPd} / \mathrm{CeO}_{2}$ catalysts calculated from the XPS results.

\begin{tabular}{lcccccccc}
\hline \multirow{2}{*}{ Catalyst } & \multicolumn{3}{c}{$\mathrm{Au}$ species $(\%)$} & & \multicolumn{3}{c}{$\mathrm{Pd}$ species (\%) } \\
\cline { 2 - 4 } \cline { 7 - 8 } & $\mathrm{Au}^{0}$ & $\mathrm{Au}^{\delta-}$ & $\mathrm{Au}^{\delta+}$ & & $\mathrm{Pd}^{0}$ & $\mathrm{Pd}^{2+}$ & $\mathrm{Pd}^{4+}$ \\
\hline $\mathrm{Au} / \mathrm{CeO}_{2}$ & 61 & 0 & 39 & & 0 & 0 & 0 \\
$3 \mathrm{Au} 1 \mathrm{Pd} / \mathrm{CeO}_{2}$ & 67 & 33 & 0 & & 48 & 52 & 0 \\
$2 \mathrm{Au} 2 \mathrm{Pd} / \mathrm{CeO}_{2}$ & 51 & 49 & 0 & & 41 & 39 & 20 \\
$1 \mathrm{Au} 3 \mathrm{Pd} / \mathrm{CeO}_{2}$ & 42 & 58 & 0 & & 30 & 31 & 39 \\
$\mathrm{Pd} / \mathrm{CeO}_{2}$ & 0 & 0 & 0 & & 19 & 25 & 56 \\
\hline
\end{tabular}

sodium benzoate and benzoic acid under solvent-free conditions. Because the desired product was of high purity (selectivity of $100 \%$ ), the yield was used to evaluate the catalytic activity. As observed, the yields obtained in the presence of the monometallic $\mathrm{Au} / \mathrm{CeO}_{2}$ and $\mathrm{Pd} / \mathrm{CeO}_{2}$ catalysts are relatively low. Following addition of the second metal, distinctly improved catalytic activity was observed. The catalyst with an $\mathrm{Au} / \mathrm{Pd}$ ratio of $3 / 1$ displayed the best catalytic performance, with a corresponding yield of $92 \%$ achieved after $8 \mathrm{~h}$ of reaction. In contrast with $\mathrm{Pd} / \mathrm{CeO}_{2}$, the yields generated in the presence of the bimetallic catalysts decreased with increasing Pd amounts. The space time yield (STY) obtained in the presence of the $\mathrm{AuPd} / \mathrm{CeO}_{2}$ catalysts was also compared, and the results are shown in Table 4. The STY values markedly increased upon introduction of $\mathrm{Pd}$ into the monometallic $\mathrm{Au} / \mathrm{CeO}_{2}$ catalyst and reached maxima at an $\mathrm{Au} / \mathrm{Pd}$ molar ratio of 3/1 (i.e., STY $2.81 \mathrm{~h}^{-1}$ ), then decreased with further increase in the loading amount of $\mathrm{Pd}$. This indicates the existence of a suitable $\mathrm{Au} / \mathrm{Pd}$ molar ratio required to generate optimal cata-

Table 4

Reactivity of benzyl alcohol oxidation over $\mathrm{AuPd} / \mathrm{CeO}_{2}$ catalysts with different $\mathrm{Au} / \mathrm{Pd}$ molar ratios.

\begin{tabular}{lccc}
\hline Catalyst & Conversion (\%) & Yield (\%) & STY a $\left(\mathrm{h}^{-1}\right)$ \\
\hline $\mathrm{Au} / \mathrm{CeO}_{2}$ & 100 & 70 & 2.14 \\
$3 \mathrm{Au} 1 \mathrm{Pd} / \mathrm{CeO}_{2}$ & 100 & 92 & 2.81 \\
$2 \mathrm{Au} 2 \mathrm{Pd} / \mathrm{CeO}_{2}$ & 100 & 83 & 2.53 \\
$1 \mathrm{Au} 3 \mathrm{Pd} / \mathrm{CeO}_{2}$ & 100 & 72 & 2.20 \\
$\mathrm{Pd} / \mathrm{CeO}$ & 100 & 55 & 1.68 \\
\hline
\end{tabular}

Reaction conditions: temperature $453 \mathrm{~K}$, reaction time $8 \mathrm{~h}, 1.08 \mathrm{~g}$ benzyl alcohol, $0.5 \mathrm{~g} \mathrm{NaOH}$, and $0.05 \mathrm{~g}$ catalyst. a The space time yield (STY) is based on the yield of benzoic acid obtained in the presence of $1 \mathrm{~g}$ catalyst per hour; the results were obtained after $8 \mathrm{~h}$ of reaction. 
lytic activity.

To examine the stability of the bimetallic catalysts, cycling experiments were conducted using the $3 \mathrm{Au} 1 \mathrm{Pd} / \mathrm{CeO}_{2}$ catalyst, and the results are shown in Fig. 8. The bimetallic catalyst was easily recovered and reused for more than seven successive reactions without significant loss in the catalytic activity, indicating the high stability of the as-prepared $\mathrm{AuPd} / \mathrm{CeO}_{2}$ catalyst.

Furthermore, the activity of the $\mathrm{AuPd} / \mathrm{CeO}_{2}$ catalyst is higher than that of previously studied $\mathrm{AuAg} / \mathrm{TiO}_{2}$ (10 h, yield $82 \%$ ) [37]. Moreover, the use of $\mathrm{AuPd} / \mathrm{CeO}_{2}$ catalyst requires lower amounts of catalyst and milder reaction conditions including a lower reaction temperature and a shorter reaction time. Therefore, the as-prepared $\mathrm{AuPd} / \mathrm{CeO}_{2}$ is an excellent catalyst candidate for the oxidation of benzyl alcohol to benzoic acid.

\subsection{Synergistic effect of the Au-Pd bimetallic catalysts}

Au-based bimetallic nanocatalysts have attracted considerable interest in the past decade owing to their improved sintering resistance and enhanced activity and selectivity. Because $\mathrm{Au}$ features a higher electronegativity (2.54) than transition metals, electron transfer from the second metal to Au may occur that will affect the catalytic performance of Au by electronic modification [55]. Wang et al. [56] reported the preparation of graphene-supported Au-Pd bimetallic nanoparticles with excellent catalytic performance towards the selective oxidation of methanol to methyl formate; additionally, their finding pointed out that electron exchange between the $\mathrm{Au}$ and Pd species would greatly facilitate the catalytic performance. The considerably lower binding energy of both $\mathrm{Au}$ and $\mathrm{Pd}$ in $\mathrm{Au}_{2.0} \mathrm{Pd}_{1.0} /$ graphene could be attributed to the electron exchange between $\mathrm{Au}$ and $\mathrm{Pd}$ (i.e., a synergism between the $\mathrm{Au}$ and $\mathrm{Pd}$ nanoparticles). Wen et al. [57] studied $\mathrm{Cu} / \mathrm{TiO}_{2}-\mathrm{SiO}_{2}$ catalysts and attributed the blue shift of $\mathrm{Cu} 2 p_{3 / 2}$ peak and unchanged Ti $2 p_{3 / 2}$ peak (which should be blue-shifted as well) binding energy to electron transfer from Ti to $\mathrm{Cu}$. Deng's group [58] also studied the surface electronic characteristics of $\mathrm{Ni}-\mathrm{B}$ and found that the binding energy of elemental B positively shifted by $\sim 1.1 \mathrm{eV}$, indicating that B partially donated electrons to Ni. In our study, clear evidence from the XPS measurements was obtained as observed by the decrease in the binding ener-

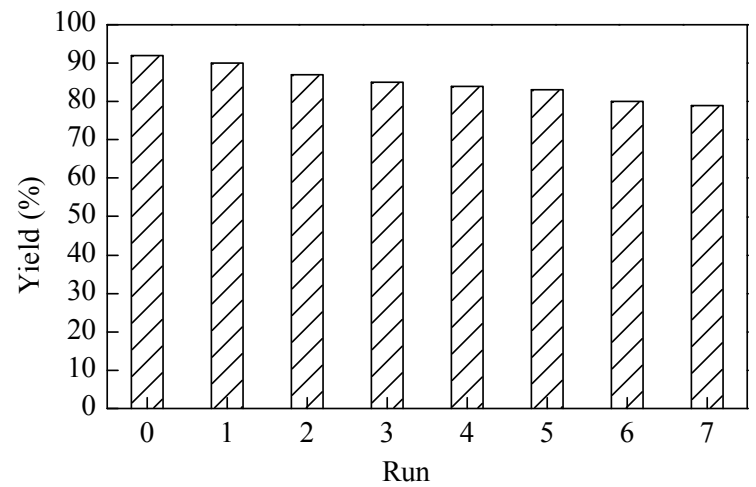

Fig. 8. Recyclability of $3 \mathrm{Au} 1 \mathrm{Pd} / \mathrm{CeO}_{2}$ towards the catalytic synthesis of sodium benzoate and benzoic acid. Reaction conditions: temperature $453 \mathrm{~K}$, reaction time $8 \mathrm{~h}, 1.08 \mathrm{~g}$ benzyl alcohol, $0.5 \mathrm{~g} \mathrm{NaOH}$, and $0.05 \mathrm{~g}$ catalyst. gy values of the $\mathrm{Au} 4 f_{7 / 2}$ levels and increase in the binding energy of the $\mathrm{Pd} 3 d_{3 / 2}$ levels in the $\mathrm{AuPd} / \mathrm{CeO}_{2}$ catalysts with varying $\mathrm{Au} / \mathrm{Pd}$ molar ratios (see Table 3 ). These results strongly suggest the interaction of electrons between the $\mathrm{Au}$ and $\mathrm{Pd}$ species. Because the physicochemical properties of both the monometallic and bimetallic catalysts are similar, except for the surface electronic properties, with changes in the $\mathrm{Au} / \mathrm{Pd}$ molar ratio, electron interaction, considered as the synergistic effect of the $\mathrm{AuPd} / \mathrm{CeO}_{2}$ catalysts, is believed to play important roles in the high catalytic performance towards the oxidation of benzyl alcohol to benzoic acid [59].

\section{Conclusions}

A systematic set of $\mathrm{AuPd} / \mathrm{CeO}_{2}$ bimetallic catalysts with different $\mathrm{Au} / \mathrm{Pd}$ molar ratios have been successfully prepared. The catalysts efficiently catalyzed the oxidation of benzyl alcohol to benzoic acid and sodium benzoate with high yields. Compared with the monometallic catalysts, the catalytic performance of $\mathrm{AuPd} / \mathrm{CeO}_{2}$ catalyst was considerably improved upon addition of the second metal. This finding could be ascribed to the formation of homogeneous Au-Pd alloy and the synergistic effect between $\mathrm{Au}$ and $\mathrm{Pd}$ that influenced the size of the metal particles and their electronic states. Optimal catalytic activity was obtained at an $\mathrm{Au} / \mathrm{Pd}$ ratio of 3/1. Moreover, this catalyst could be recycled by simple treatment and reused numerous times without significant loss of activity.

\section{References}

[1] Moskovits M, Srnova-Sloufova I, Vlckova B. J Chem Phys, 2002, 116: 10435

[2] Kim M J, Na H J, Lee K C, Yoo E A, Lee M Y. J Mater Chem, 2003, 13: 1789

[3] Xu J, White T, Li P, He C H, Yu J G, Yuan W K, Han Y F. J Am Chem Soc, 2010, 132: 10398

[4] Zhang G J, Wang Y E, Wang X, Chen Y, Zhou Y M, Tang Y W, Lu L D, Bao J C, Lu T H. Appl Catal B, 2011, 102: 614

[5] Pina C D, Falletta E, Prati L, Rossi M. Chem Soc Rev, 2008, 37: 2077

[6] Ishida T, Kinoshita N, Okatsu H, Akita T, Takei T, Haruta M. Angew Chem Int Ed, 2008, 47: 9265

[7] Parreira L A, Bogdanchikova N, Pestryakov A, Zepeda T A, Tuzovskaya I, Farias M H, Gusevskaya E V. Appl Catal A, 2011, 397 : 145

[8] Menegazzo F, Signoretto M, Manzoli M, Boccuzzi F, Cruciani G, Pinna F, Strukul G. J Catal, 2009, 268: 122

[9] Cui X J, Shi F, Deng Y Q. Chem Commun, 2012, 48: 7586

[10] Xiang Y Z, Meng Q Q, Li X N, Wang J G. Chem Commun, 2010, 46: 5918

[11] Wang X G, Venkataramanan N S, Kawanami H, Ikushima Y. Green Chem, 2007, 9: 1352

[12] Kesavan L, Tiruvalam R, Ab Rahim M H, bin Saiman M I, Enache D I, Jenkins R L, Dimitratos N, Lopez-Sanchez J A, Taylor S H, Knight D W, Kiely C J, Hutchings G J. Science, 2011, 331: 195

[13] Liu H L, Li Y W, Jiang H F, Vargas C, Luque R. Chem Commun, 2012, 48: 8431

[14] Enache D I, Edwards J K, Landon P, Solsona-Espriu B, Carley A F, Herzing A A, Watanabe M, Kiely C J, Knight D W, Hutchings G J. Science, 2006, 311: 362 


\section{Graphical Abstract}

Chin. J. Catal., 2014, 35: 1846-1857 doi: 10.1016/S1872-2067(14)60159-5

\section{Synergistic effect on Au-Pd bimetallic catalyst during oxidation of benzyl alcohol to sodium benzoate}

Zhaoyan Zhang, Ying Wang, Xian Li, Wei-Lin Dai* Fudan University

A series of $\mathrm{AuPd} / \mathrm{CeO}_{2}$ bimetallic catalysts with different $\mathrm{Au} / \mathrm{Pd}$ molar ratios were successfully prepared and applied in the catalytic oxidation of benzyl alcohol to benzoic acid and sodium benzoate with high yields. The $3 \mathrm{Au} 1 \mathrm{Pd} / \mathrm{CeO}_{2}$ catalyst shows optimal performance and was easily recovered and reused for more than seven successive reactions without significant loss of activity, which was attributed to the synergistic effect between $\mathrm{Au}$ and Pd.

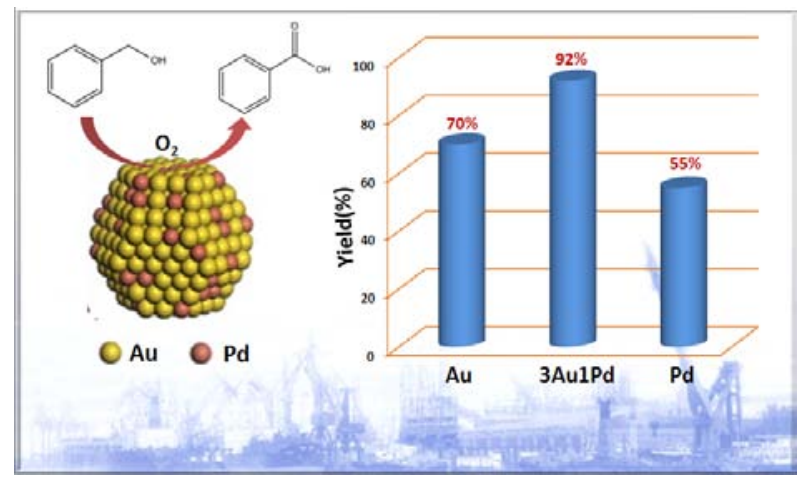

[15] Shi Y, Yang H M, Zhao X G, Cao T, Chen J Z, Zhu W W, Yu Y Y, Hou Z S. Catal Commun, 2012, 18: 142

[16] Miedziak P J, Tang Z R, Davies T E, Enache D I, Bartley J K, Carley A F, Herzing A A, Kiely C J, Taylor S H, Hutchings G J. J Mater Chem, 2009, 19: 8619

[17] Lee Y W, Kim M, Kim Y, Kang S W, Lee J H, Han S W. J Phys Chem C, 2010, 114: 7689

[18] Gu X J, Lu Z H, Jiang H L, Akita T, Xu Q. J Am Chem Soc, 2011, 133: 11822

[19] Chen M S, Kumar D, Yi C W, Goodman D W. Science, 2005, 310: 291

[20] Cardenas-Lizana F, Gomez-Quero S, Hugon A, Delannoy L, Louis C, Keane M A. J Catal, 2009, 262: 235

[21] Ma C Y, Dou B J, Li J J, Cheng J, Hu Q, Hao Z P, Qiao S Z. Appl Catal B, 2009, 92: 202

[22] Zhan G W, Hong Y L, Mbah V T, Huang J L, Ibrahim A R, Du M M, Li Q B. Appl Catal A, 2012, 439-440: 179

[23] Tamura M, Tonomura T, Shimizu K, Satsuma A. Green Chem, 2012, 14: 717

[24] Tamura M, Tonomura T, Shimizu K, Satsuma A. Green Chem, 2012, 14: 984

[25] Honda M, Sonehara S, Yasuda H, Nakagawa Y, Tomishige K. Green Chem, 2011, 13: 3406

[26] Tamura M, Tonomura T, Shimizu K, Satsuma A. Appl Catal A, 2012, 417-418: 6

[27] Krishna K, Seijger G B F, van den Bleek C M, Calis H P A. Chem Commun, 2002: 2030

[28] Min B K, Friend C M. Chem Rev, 2007, 107: 2709

[29] Schubert M M, Hackenberg S, van Veen A C, Muhler M, Plzak V, Behm R J.J Catal, 2001, 197: 113

[30] Carrettin S, Concepcion P, Corma A, Lopez Nieto J M, Puntes V F. Angew Chem Int Ed, 2004, 43: 2538

[31] Corma A, Domine M E. Chem Commun, 2005: 4042

[32] Tada M, Bal R, Mu X D, Coquet R, Namba S, Iwasawa Y. Chem Commun, 2007: 4689

[33] Miura H, Wada K, Hosokawa S, Sai M, Kondo T, Inoue M. Chem Commun, 2009: 4112

[34] Sato T, Komanoya T. Catal Commun, 2009, 10: 1095

[35] Concepcion P, Corma A, Silvestre-Albero J, Franco V, Chane-Ching J Y.J Am Chem Soc, 2004, 126: 5523

[36] Matsumura Y, Shen W J, Ichihashi Y, Okumura M. Chem Lett, 1999: 1101
[37] Wang Y, Zheng J M, Fan K N, Dai W L. Green Chem, 2011, 13: 1644

[38] Li X, Zheng J M, Yang X L, Dai W L, Fan K N. Chin J Catal (李娴, 郑嘉 旻, 杨新丽, 戴维林, 范康年. 催化学报), 2013, 34: 1013

[39] Cui Y Y, Wang Y, Fan K N, Dai W L. Appl Surf Sci, 2013, 279: 391

[40] Nowicka E, Hofmann J P, Parker S F, Sankar M, Lari G M, Kondrat S A, Knight D W, Bethell D, Weckhuysen B M, Hutchings G J. Phys Chem Chem Phys, 2013, 15: 12147

[41] Tauster S J, Fung S C, Garten R L. J Am Chem Soc, 1978, 100: 170

[42] Jana D, Dandapat A, De G. J Phys Chem C, 2009, 113: 9101

[43] Link S, Wang Z L, El-Sayed M A.J Phys Chem B, 1999, 103: 3529

[44] Toshima N, Harada M, Yamazaki Y, Asakura K. J Phys Chem, 1992, 96: 9927

[45] Creighton J A, Eadon D G. J Chem Soc, Faraday Trans, 1991, 87: 3881

[46] Scott R W J, Wilson O M, Oh S K, Kenik E A, Crooks R M. J Am Chem Soc, 2004, 126: 15583

[47] Ferrer D, Torres-Castro A, Gao X, Sepulveda-Guzman S, Ortiz-Mendez U, Jose-Yacaman M. Nano Lett, 2007, 7: 1701

[48] Berlowitz P J, Peden C H F, Goodman D W. J Phys Chem, 1988, 92: 5213

[49] Yi C W, Luo K, Wei T, Goodman D W. J Phys Chem B, 2005, 109: 18535

[50] Han Y F, Zhong Z Y, Ramesh K, Chen F X, Chen L W, White T, Tay Q, Yaakub S N, Wang Z. J Phys Chem C, 2007, 111: 8410

[51] Chou T S, Periman M L, Watson R E. Phys Rev B, 1976, 14: 3248

[52] Nascente P A P, de Castro S G C, Landers R, Kleiman G G. Phys Rev $B, 1991,43: 4659$

[53] Deki S, Akamatsu K, Hatakenaka Y, Mizuhata M, Kajinami A. Nanostruct Mater, 1999, 11: 59

[54] Jose-Yacaman M, Mejia-Rosales S, Perez-Tijerina E, Blom D A, Allard L F. Microsc Microanal, 2006, 12: 772

[55] Wang A Q Liu XY, Mou C Y, Zhang T. J Catal, 2013, 308: 258

[56] Wang R Y, Wu Z W, Chen C M, Qin Z F, Zhu H Q, Wang G F, Wang H, Wu C M, Dong W W, Fan W B, Wang J G. Chem Commun, 2013, 49: 8250

[57] Wen C, Yin A Y, Cui Y Y, Yang X L, Dai W L, Fan K N. Appl Catal A, 2013, 458: 82

[58] Li H, Li H X, Dai W L, Wang W J, Fang Z G, Deng J F. Appl Surf Sci, 1999, 152: 25

[59] Liu J H, Wang A Q, Chi Y S, Lin H P, Mou C Y.J Phys Chem B, 2005, 109: 40 


\title{
苯甲醇氧化制苯甲酸钠反应中金钯双金属催化剂的协同效应
}

\author{
张召艳, 王英, 李 娴, 戴维林 ${ }^{*}$ \\ 复旦大学化学系, 上海市分子催化和功能材料重点实验室, 上海200433
}

\begin{abstract}
摘要: 研究了不同 $\mathrm{Au} / \mathrm{Pd}$ 摩尔比的 $\mathrm{AuPd} / \mathrm{CeO}_{2}$ 双金属催化剂在苯甲醇氧化制苯甲酸及其钠盐反应中的催化活性, 利用 XRD, UV-Vis DRS, TEM和XPS等手段对催化剂的结构进行了系统考察. 结果表明, Au-Pd纳米颗粒以合金形式分散在 $\mathrm{CeO}_{2}$ 载体上, 不 同 $\mathrm{Au} / \mathrm{Pd}$ 摩尔比会影响催化剂表面活性物种的粒径大小和尺寸分布, 并改变催化剂表面物种的组成. $\mathrm{Au}-\mathrm{Pd}$ 之间的电子效应和协 同效应显著影响其催化活性. 当 $\mathrm{Au} / \mathrm{Pd}$ 摩尔比为 3 时催化剂表现出最好的催化活性, 苯甲酸产率可达 $92 \%$. 此外, 双金属催化剂的 催化活性显著优于单金属催化剂, 主要归因于 $\mathrm{Au}$ 和Pd之间的协同效应. $\mathrm{AuPd} / \mathrm{CeO}_{2}$ 催化剂还具有良好的稳定性, $\mathrm{Au} / \mathrm{Pd}$ 摩尔比为 3 的 $\mathrm{AuPd} / \mathrm{CeO}_{2}$ 催化剂使用7次后仍然具有较高的催化活性.
\end{abstract}

关键词: 金; 钯; 氧化铈; 双金属催化剂; 苯甲醇; 催化氧化; 苯甲酸盐

收稿日期: 2014-05-06. 接受日期: 2014-05-26. 出版日期: 2014-11-20.

*通讯联系人. 电话: (021)55664678; 传真: (021)55665701; 电子信箱：wldai@fudan.edu.cn

基金来源: 国家重点基础研究发展计划(973计划, 2012CB224804); 国家自然科学基金(21373054, 21173052); 上海市科学技术委 员会上海市自然科学基金(08DZ2270500).

本文的英文电子版由Elsevier出版社在ScienceDirect上出版(http://www.sciencedirect.com/science/journal/18722067).

\section{1. 前言}

负载型双金属催化剂由于具有独特的催化活性, 近 年来在催化领域引起广泛关注 ${ }^{[1-4]}$.与单金属催化剂相 比, 双金属催化剂中第二种金属的加入可以调节和改变 催化剂的形貌和电子特性, 从而提高催化剂的活性和稳 定性 ${ }^{[5-8]}$. 其中, Au-Pd双金属催化剂在诸多反应体系中 具有很好的活性, 如甲苯氧化消除 ${ }^{[9]}$ 、硝基苯还原 ${ }^{[10]}$ 、 低碳烷烃氧化 ${ }^{[11-13]}$ 以及醇类氧化 ${ }^{[14,15]}$ 等. 目前, 关于 $\mathrm{Au}-\mathrm{Pd}$ 合金催化剂相对于单独 $\mathrm{Au}$ 和Pd催化剂的促进作 用得到了广泛关注 ${ }^{[16-18]}$. Goodman课题组 ${ }^{[19]}$ 研究了乙酸 乙烯酯合成反应中 $\mathrm{Pd} / \mathrm{Au}(111)$ 和 $\mathrm{Pd} / \mathrm{Au}(100)$ 催化剂表面 结构, 指出 $\mathrm{AuPd}$ 合金明显提高了催化剂的活性和选择 性. Keane课题组 ${ }^{[20]}$ 研究发现, 在对氯硝基苯还原反应中 $\mathrm{Au}-\mathrm{Pd} / \mathrm{Al}_{2} \mathrm{O}_{3}$ 催化剂比 $\mathrm{Au} / \mathrm{Al}_{2} \mathrm{O}_{3}$ 单金属催化剂具有更好 的催化活性. Hao课题组 ${ }^{[21]}$ 发现将Pd加入到Au/SBA-15 中可以降低纳米 $\mathrm{Au}$ 的粒径尺寸, 从而提高催化剂在苯甲 醇氧化反应中的催化活性. Huang 课题组 ${ }^{[22]}$ 报道了 $\mathrm{AuPd} / \mathrm{MgO}$ 催化剂中 $\mathrm{Au} / \mathrm{Pd}$ 摩尔比对苯甲醇氧化制苯甲 醛的影响. 但是关于 $\mathrm{Au}-\mathrm{Pd}$ 双金属催化剂用于苯甲醇氧 化制苯甲酸盐和苯甲酸反应的报道并不多见.

二氧化铈 $\left(\mathrm{CeO}_{2}\right)$ 在多种有机反应中是一种有效的 催化剂, 如酰胺交换 ${ }^{[23]}$ 、腈类和醇类合成酯 ${ }^{[24]}$ 、氨基甲 酸盐制备 ${ }^{[25]}$ 、烷基酰胺合成 ${ }^{[26]}$ 以及 $\mathrm{NO}_{x}$ 还原 ${ }^{[27]}$ 等反应. $\mathrm{CeO}_{2}$ 由于具有酸碱性和氧化还原性能, 被广泛用作催化 剂载体 ${ }^{[28,29]}$, 在其上负载 $\mathrm{Au}^{[30,31]}, \mathrm{Cu}^{[32]}, \mathrm{Ru}^{[33,34]}, \mathrm{Pt}^{[35]}$ 和 $\mathrm{Pd}^{[36]}$ 等制备的催化剂被用在各种无机或有机反应中.
此外, 有研究指出在 $\mathrm{CO}$ 氧化反应中 $\mathrm{Au} / \mathrm{CeO}_{2}$ 催化剂比 $\mathrm{Au} / \mathrm{TiO}_{2}$ 和 $\mathrm{Au} / \mathrm{Fe}_{2} \mathrm{O}_{3}$ 催化剂具有更好的催化性能 ${ }^{[30]}$. 因 此, $\mathrm{CeO}_{2}$ 是一种理想的负载 $\mathrm{Au}$ 和其他贵金属的载体.

苯甲酸钠和苯甲酸是重要的精细化工产品, 主要应 用于食品添加剂、防腐剂、香料、塑化剂和媒染剂. 在 苯甲醇氧化合成反应中, 无溶剂、一锅法合成是一种环 境友好、无毒、高效的催化路线 ${ }^{[37]}$. 我们之前的研究 ${ }^{[37]}$ 发现, $\mathrm{AuAg} / \mathrm{TiO}_{2}$ 双金属催化剂在苯甲醇氧化反应中表 现出很好的稳定性, 并且当 $\mathrm{Au} / \mathrm{Ag}$ 摩尔比为 $1 / 3$ 时, 催化 剂表现出最好的活性. 为了进一步提高催化活性和探讨 $\mathrm{Au}$ 与 $\mathrm{Pd}$ 之间的协同效应, 我们研究了 $\mathrm{AuPd} / \mathrm{CeO}_{2}$ 双金属 催化剂的制备、结构及其在苯甲醇氧化制苯甲酸钠和苯 甲酸反应中的催化性能. 采用共沉淀方法制备了一系列 不同 $\mathrm{Au} / \mathrm{Pd}$ 摩尔比的催化剂, 采用紫外-可见漫反射光谱 (UV-Vis DRS)、透射电镜(TEM)和X射线光电子能谱 (XPS) 等手段对催化剂进行了结构表征. 结果发现 $\mathrm{Au}-\mathrm{Pd}$ 纳米颗粒主要以合金形式存在, 并且当 $\mathrm{Au} / \mathrm{Pd}$ 摩尔 比为 $3 / 1$ 时催化剂具有最高催化活性.

\section{2. 实验部分}

\section{1. 催化剂的制备}

负载在不同载体上的 $\mathrm{Au}-\mathrm{Pd}(\mathrm{Au} / \mathrm{Pd}=1 / 1)$ 双金属催 化剂的制备方法如下. 首先通过沉积-沉淀(DP)法, 以尿 素为沉淀剂将 $\mathrm{Au}$ 负载在载体上. 将 $1.0 \mathrm{~g}$ 载体 $\left(\mathrm{TiO}_{2}\right.$, $\mathrm{MnO}_{2}, \mathrm{SnO}_{2}, \mathrm{ZnO}$ 或 $\left.\mathrm{CeO}_{2}\right), 9 \mathrm{~mL} \mathrm{HAuCl}_{4}$ 溶液 (24.3 $\mathrm{mmol} / \mathrm{L}$ )和 $2.6 \mathrm{~g}$ 尿素加入到 $80 \mathrm{~mL}$ 蒸馏水中并不断搅拌; 然后将混合物置于 $353 \mathrm{~K}$ 水浴中搅拌 $2 \mathrm{~h}$, 溶液的 $\mathrm{pH}$ 逐渐 
从3.0增加到 8.0 , 抽滤, 用蒸馏水洗涤3次, 得到的固体置 于 $373 \mathrm{~K}$ 下烘干过夜, 最后在 $573 \mathrm{~K}$ 下焙烧 $4 \mathrm{~h}$. 其次通过 浸渍法将Pd负载到上述合成的前驱体上. 将 $1.0 \mathrm{~g}$ 上述前 驱体加入到 $7.2 \mathrm{~mL} \mathrm{PdCl}$ 溶液 $(56.3 \mathrm{mmol} / \mathrm{L}$ )中, 并加入 $40 \mathrm{~mL}$ 蒸馏水, 在 $353 \mathrm{~K}$ 下搅拌, 直至水分全部蒸干, 所得 固体在 $373 \mathrm{~K}$ 下干燥, 并在 $673 \mathrm{~K}$ 下焙烧 $4 \mathrm{~h}$. 所得催化剂 即为 $\mathrm{AuPd} / \mathrm{MO}\left(\mathrm{MO}=\mathrm{TiO}_{2}, \mathrm{MnO}_{2}, \mathrm{SnO}_{2}, \mathrm{ZnO}\right.$ 或 $\left.\mathrm{CeO}_{2}\right)$. 所有 $\mathrm{AuPd} / \mathrm{MO}$ 催化剂中金属整体负载量为 $8 \mathrm{wt} \%$, 并且 $\mathrm{Au} / \mathrm{Pd}$ 摩尔比为 $1 / 1$.

单金属 $\mathrm{Au} / \mathrm{CeO}_{2}$ 催化剂以尿素为沉淀剂, 通过DP法 制备. 将 $1.0 \mathrm{~g} \mathrm{CeO}_{2}, 18 \mathrm{~mL} \mathrm{HAuCl}_{4}$ 溶液 $(24.3 \mathrm{mmol} / \mathrm{L}$ )和 $5.2 \mathrm{~g}$ 尿素加入到 $80 \mathrm{~mL}$ 蒸馏水中并不断搅拌. 将混合物 置于 $353 \mathrm{~K}$ 水浴中搅拌 $2 \mathrm{~h}$ 后, 抽滤, 用蒸馏水洗涤 3 次, 得 到的固体置于 $373 \mathrm{~K}$ 下烘干过夜, 然后在 $573 \mathrm{~K}$ 下焙烧 4 h.

单金属 $\mathrm{Pd} / \mathrm{CeO}_{2}$ 催化剂通过浸渍法制备. 将 $1.0 \mathrm{~g}$ $\mathrm{CeO}_{2}$ 加入到 $14.5 \mathrm{~mL} \mathrm{PdCl} 2$ 溶液 $(56.3 \mathrm{mmol} / \mathrm{L}$ ) 和 $80 \mathrm{~mL}$ 的 蒸馏水中, 产生的混浊液在 $353 \mathrm{~K}$ 下搅拌直到水分全部 蒸干, 所得固体在 $373 \mathrm{~K}$ 下干燥, 并在 $673 \mathrm{~K}$ 下焙烧 $4 \mathrm{~h}$.

不同 $\mathrm{Au} / \mathrm{Pd}$ 摩尔比的双金属催化剂制备过程如下. 首先通过DP法制备 $\mathrm{Au} / \mathrm{CeO}_{2}$ (与单金属 $\mathrm{Au} / \mathrm{CeO}_{2}$ 制备相 同), 然后通过浸渍法将 $\mathrm{Pd}$ 负载到 $\mathrm{Au} / \mathrm{CeO}_{2}$ 上(类似于单 金属 $\mathrm{Pd} / \mathrm{CeO}_{2}$ 的制备)得到 $\mathrm{AuPd} / \mathrm{CeO}_{2}$ 催化剂. 催化剂中 $\mathrm{AuPd}$ 整体负载量控制在 $8 \mathrm{wt} \% . \mathrm{Au} / \mathrm{Pd}$ 摩尔比为 $3 / 1,2 / 2$ 和 $1 / 3$ 的催化剂分别记为 $3 \mathrm{Au} 1 \mathrm{Pd} / \mathrm{CeO}_{2}, 2 \mathrm{Au} 2 \mathrm{Pd} / \mathrm{CeO}_{2}$ 和 $1 \mathrm{Au} 3 \mathrm{Pd} / \mathrm{CeO}_{2}$.

将反应后催化剂用稀 $\mathrm{HCl}$ 洗涤 3 次, 然后在 $573 \mathrm{~K}$ 下焙烧 $4 \mathrm{~h}$, 用于下次循环反应实验.

\section{2. 催化剂的表征}

催化剂的比表面积和孔分布采用美国Micromeritics 公司 Tristar 3000型自动物理吸附仪测定, 在液氮温度 77 $\mathrm{K}$ 下获得样品的 $\mathrm{N}_{2}$ 吸附/脱附等温线. $\mathrm{Au}$ 和 $\mathrm{Pd}$ 的负载量 使用电感耦合等离子体发射光谱测定, 采用的仪器型号 为IRIS Intrepid (美国Thermo Elemental公司). 采用德国 Bruker公司D8 Advance型X射线粉末衍射仪进行催化剂 样品的物相分析, 射线源采用波长为 $0.154 \mathrm{~nm}$ 的 $\mathrm{Cu} K_{\alpha}$ 线, 采用Goebel镜将发散X光束汇聚为平行光, 管电压为 $40 \mathrm{kV}$, 管电流为 $40 \mathrm{~mA}$. XPS 采用 PerkinElmer PHI $5000 \mathrm{C}$ ESCA System X射线光电子能谱仪, 以 $\mathrm{Mg} K_{a}$ 射线 $(1253.6 \mathrm{eV})$ 作为光源, 分析器通能为 $93.9 \mathrm{eV}$, 分析室的 压力 $<10^{-6} \mathrm{~Pa}$. 样品压片后测试, 所有结合能均以污染 碳 $(\mathrm{C} 1 s=284.6 \mathrm{eV})$ 进行校正. TEM仪器型号为 JEOL
2011 TEM. 紫外-可见漫反射光谱测试采用 Shimadzu UV-2450型紫外-可见分光光度计, 将粉末样品装入样品 池中, 以 $\mathrm{BaSO}_{4}$ 为参比测定, 扫描范围200-800 nm.

\section{3. 催化剂活性测试}

所有实验均在装有冷凝回流装置的圆底烧瓶中进 行. 反应温度为 $453 \mathrm{~K}$, 称取 $1.08 \mathrm{~g}$ 苯甲醇、 $0.05 \mathrm{~g}$ 催化剂 和 $0.5 \mathrm{~g} \mathrm{NaOH}$ 于圆底烧瓶中, 然后置于油浴中搅拌, 453 $\mathrm{K}$ 加热回流 $8 \mathrm{~h}$. 然后加入 $12 \mathrm{~mL}$ 水, 离心分离除去催化 剂, 滤液蒸发结晶得到苯甲酸钠, 纯度 $>99 \%$.

另外, 将上述滤液用 $\mathrm{HCl}$ 进行酸化至 $\mathrm{pH}<2.0$, 有白 色固体出现, 静置后抽滤, 获得白色的苯甲酸固体, 在空 气中干燥后称重. 苯甲酸得率 $=$ (苯甲酸摩尔量 $/$ 苯甲醇 摩尔量) $\times 100 \%$.

\section{3. 结果与讨论}

\section{1. 载体对AuPd双金属催化剂的影响}

载体效应是影响催化剂活性的重要因素. 载体的比 表面积、表面酸碱性、特殊的表面官能团以及载体与金 属之间的相互作用等都会影响催化反应的活性. 不同载 体负载的AuPd催化剂在苯甲醇氧化制苯甲酸和苯甲酸 钠反应中的催化活性示于图1. 可以看出, 具有较多碱 性位的 $\mathrm{MnO}_{2}$ 和 $\mathrm{SnO}_{2}$ 负载的 $\mathrm{AuPd}$ 双金属催化剂, 催化 活性最差, 这可能是由于催化剂中具有较多的碱性位 和较小的比表面积 ${ }^{[38]}$. 以 $\mathrm{TiO}_{2}$ 和 $\mathrm{ZnO}$ 为载体的催化剂 的催化活性比 $\mathrm{MnO}_{2}$ 和 $\mathrm{SnO}_{2}$ 负载的催化剂好. 我们先 前研究发现 $\mathrm{AuAg} / \mathrm{TiO}_{2}$ 催化剂对于苯甲醇制苯甲酸钠 反应是一种优良的催化剂 ${ }^{[39]}$, 但是苯甲酸钠得率只有 $78 \%$ 左右, 并且该催化剂在没有保护剂的作用下很容 易发生聚集. 而 $\mathrm{AuPd} / \mathrm{ZnO}$ 催化剂的活性比 $\mathrm{AuPd} / \mathrm{CeO}_{2}$ 低, 这可能是由于 $\mathrm{ZnO}$ 载体缺乏一定量的酸性位 ${ }^{[40]}$. 而对于 $\mathrm{AuPd} / \mathrm{CeO}_{2}$, 催化剂中存在较多的酸性位和具 有较大的比表面积, 并且金属与载体之间存在着强相 互作用, 使得该催化剂具有较好的活性和稳定性 ${ }^{[41]}$. 因此, $\mathrm{CeO}_{2}$ 被选作载体进行深入研究.

\section{2. 催化剂的表征结果}

\subsection{1. $\mathrm{N}_{2}$ 吸附和ICP-AES结果}

各催化剂的物理化学性质如表1所示. 负载双金 属后的催化剂的比表面积有稍许增加. 不同催化剂的 孔体积和平均孔径没有明显区别, 说明金属物种的引 入对催化剂结构没有造成影响. 从 ICP测试结果可以 看出, 实际的 $\mathrm{Au}$ 和 $\mathrm{Pd}$ 负载量和其理论值相近, 说明 $\mathrm{Au}$ 和Pd都有效负载在 $\mathrm{CeO}_{2}$ 载体上. 


\subsubsection{XRD结果}

不同 $\mathrm{Au} / \mathrm{Pd}$ 摩尔比的 $\mathrm{AuPd} / \mathrm{CeO}_{2}$ 双金属催化剂的 $\mathrm{XRD}$ 结果如图2所示. 可以看出, 在 $2 \theta=38.2^{\circ}$ 处可以观 察到 $\mathrm{Au}$ 的衍射峰, 并且随着 $\mathrm{Pd}$ 含量的增加, $\mathrm{Au}$ 的衍射峰 强度逐渐减弱. 在 $2 \theta=40.1^{\circ}$ 处可以观察到金属Pd的微 弱且宽化的衍射峰 (图 2 (2)-(5)), 说明 Pd成功负载在 $\mathrm{AuPd}$ 双金属催化剂上. 对于双金属 $\mathrm{AuPd} / \mathrm{CeO}_{2}, \mathrm{Au}$ 的衍 射峰从 $2 \theta=38.2^{\circ}$ 偏移到 $38.9^{\circ}$, 并且衍射峰位于单独的 $\mathrm{Au}$ 和单独的 $\mathrm{Pd}$ 的衍射峰值之间, 这说明有部分 $\mathrm{Au}$ 和 $\mathrm{Pd}$ 在制备过程中形成了合金 ${ }^{[42]}$. 在单金属 $\mathrm{Pd} / \mathrm{CeO}_{2}$ (图 2(5)) 中出现了 $\mathrm{PdO}$ 的微弱衍射峰, 该峰非常微弱且宽化, 说明 PdO的粒径非常小; $\mathrm{PdO}$ 的出现可能是催化剂在制 备过程中, 在空气中焙烧时少量的Pd被氧化形成的. 由 $\mathrm{XRD}$ 结果可以看出, 在双金属催化剂中同时存在着 $\mathrm{PdO}$ 和Pd物种.

\subsubsection{UV-Vis DRS结果}

不同 $\mathrm{Au} / \mathrm{Pd}$ 摩尔比的 $\mathrm{AuPd} / \mathrm{CeO}_{2}$ 双金属催化剂的紫 外-可见漫反射光谱如图3所示. $\mathrm{Au}$ 在 $570 \mathrm{~nm}$ 左右有一个 微弱的宽吸收峰, 对应的是金属态金 $\left(\mathrm{Au}^{0}\right)$ 的等离子共振 峰 $(\mathrm{SPR})^{[43]}$. 加入 $\mathrm{Pd}$ 形成双金属催化剂以后, 等离子共 振吸收峰有一个明显的红移. 这可能是由于形成双金属 $\mathrm{AuPd}$ 合金后能带间发生了电子跃迁 ${ }^{[44-47]}$. 这一现象说 明催化剂中的金属以AuPd合金的形式存在, 而不是以单 独的 $\mathrm{Au}$ 和Pd存在. AuPd合金的形成能很好地加强电子 之间的相互作用, 这可能是催化剂活性提高的一个重要 原因.

\subsubsection{TEM结果}

不同 $\mathrm{Au} / \mathrm{Pd}$ 摩尔比的 $\mathrm{AuPd} / \mathrm{CeO}_{2}$ 催化剂的透射电镜 照片和金属的粒径分布如图4所示. 可以看出, 金属颗粒 均匀分散在载体表面. 单金属的 $\mathrm{Au} / \mathrm{CeO}_{2}$ 催化剂中金属 的平均粒径是 $4.5 \mathrm{~nm}$, 粒径分布较窄. 单金属 $\mathrm{Pd} / \mathrm{CeO}_{2}$ 催 化剂上金属的平均粒径是 $5.2 \mathrm{~nm}$, 粒径分布较宽. 然而 在双金属催化剂中, 随着 $\mathrm{Pd}$ 含量的增加, 金属颗粒的平 均粒径逐渐增加, 从 $4.8 \mathrm{~nm}$ 增加到 $5.7 \mathrm{~nm}$. 其中, $3 \mathrm{Au} 1 \mathrm{Pd} / \mathrm{CeO}_{2}$ 催化剂的平均粒径最小, 这可能是其活性 好的原因之一.

\subsubsection{XPS结果}

不同 $\mathrm{Au} / \mathrm{Pd}$ 摩尔比的 $\mathrm{AuPd} / \mathrm{CeO}_{2}$ 的XPS谱如图5-7所 示, 催化剂表面 $\mathrm{Au}$ 和Pd的元素组成列于表 2 和表 3 . 从表 2 可以明显看出, $\mathrm{Au}$ 和Pd的表面含量明显高于体相中的 含量, 但是表面 $\mathrm{Au} / \mathrm{Pd}$ 摩尔比只是稍高于化学计量的 $\mathrm{Au} / \mathrm{Pd}$ 摩尔比, 说明 $\mathrm{AuPd} / \mathrm{CeO}_{2}$ 是表面富 $\mathrm{Au}$. 文献 ${ }^{[48,49]}$ 在
研究Pd-Au催化剂时也发现了 $\mathrm{Au}$ 在催化剂表面富集的 现象.

此外, 由于 $\mathrm{Au}^{0} 4 d_{5 / 2}(333.8 \mathrm{eV})$ 和 $\mathrm{Pd}^{0} 3 d_{5 / 2}(334.0 \mathrm{eV})$ 以及 $\mathrm{Au}^{0} 4 f_{5 / 2}(87.7 \mathrm{eV})$ 和 $\mathrm{Pd}^{0} 4 s(88.2 \mathrm{eV})$ 有部分重

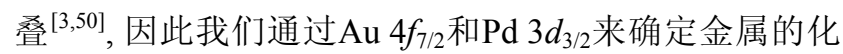
合态. 在单金属 $\mathrm{Au} / \mathrm{CeO}_{2}$ 催化剂中, $\mathrm{Au} 4 f_{7 / 2}$ 的结合能是 $83.7 \mathrm{eV}$, 对其进行分峰拟合后发现, $\mathrm{Au}$ 物种有 $\mathrm{Au}^{\delta+}$ 和 $\mathrm{Au}^{0}$ 两种存在形式. 随着 $\mathrm{Pd}$ 含量的增加, $\mathrm{Au} 4 f_{7 / 2}$ 峰位置 向低结合能方向移动, 并且在双金属催化剂中 $\mathrm{Au}^{\delta+}$ 消失, 表面 $\mathrm{Au}$ 的存在状态变为 $\mathrm{Au}^{0}$ 和 $\mathrm{Au}^{\delta-}$, 并且 $\mathrm{Au}^{\delta-}$ 的含量随 着Pd含量的增加而增加. 这可能是由于 $P d$ 的加入增加 了电子之间的相互作用, 催化剂表面Pd的部分电荷转移 到 $\mathrm{Au}$ 簇上面, 造成 $\mathrm{Au}$ 表面电荷富集, 从而导致 $\mathrm{Au}^{\delta-}{ }^{\delta}$ 物种 的生成.

对于单金属 $\mathrm{Pd} / \mathrm{CeO}_{2}$ 催化剂, $\mathrm{Pd}$ 的物种为 $\mathrm{Pd}^{0}, \mathrm{Pd}^{2+}$ 和 $\mathrm{Pd}^{4+} . \mathrm{Pd}^{\delta+}$ 的形成可能是由于在制备过程中, 在空气中 焙烧时有部分 $\mathrm{Pd}$ 被氧化. 当 $\mathrm{Au}$ 含量增加时, $\mathrm{Pd} 3 d_{3 / 2}$ 峰出 现明显的位移, Pd $3 d_{3 / 2}$ 的结合能逐渐降低(图5(b)). Au $4 f_{7 / 2}$ 和 $\mathrm{Pd} 3 d_{3 / 2}$ 结合能位置的改变表明了电子在 $\mathrm{Au}$ 和 $\mathrm{Pd}$ 之间的流动 ${ }^{[51-54]}$. 此外, 我们发现随着 $\mathrm{Au}$ 含量的增加, $\mathrm{Pd}^{\delta+}$ 物种的含量逐渐降低, 转变为金属态的 $\mathrm{Pd}$ (见表3). 这可能是由于 $\mathrm{Au}$ 和Pd之间的协同效应, $\mathrm{Au}$ 倾向于获得 电子, 而Pd容易失去电子.

\section{3. 催化剂的活性}

在无溶剂的碱性条件下, 苯甲醇氧化合成苯甲酸钠 属于Cannizzaro反应. 在这一反应中, 苯甲醇首先被氧化 生成苯甲醛, 苯甲醛在碱性条件下立即转化形成苯甲酸 钠.

不同 $\mathrm{Au} / \mathrm{Pd}$ 摩尔比的 $\mathrm{AuPd} / \mathrm{CeO}_{2}$ 催化剂在苯甲醇氧 化制苯甲酸和苯甲酸钠反应中的活性测试结果见表4. 可以看出, 用单金属催化剂 $\mathrm{Au} / \mathrm{CeO}_{2}$ 和 $\mathrm{Pd} / \mathrm{CeO}_{2}$ 催化该反 应体系时, 产物得率均较低. 当加入第二种金属后, 催化 剂活性得到明显提高, 并且当 $\mathrm{Au} / \mathrm{Pd}$ 摩尔比为 $3 / 1$ 时催化 活性最好, 得率可达 $92 \%$; 但是再增加Pd的含量时, 催化 剂活性开始明显下降. $\mathrm{AuPd} / \mathrm{CeO}_{2}$ 催化剂的时空产率也 列于表4. 当 $\mathrm{Pd}$ 加入到 $\mathrm{Au} / \mathrm{CeO}_{2}$ 催化剂中时, 时空产率明 显增加, 并且当 $\mathrm{Au} / \mathrm{Pd}$ 摩尔比为 $3 / 1$ 时达到最大值, 为 2.81 $\mathrm{h}^{-1}$, 进一步增加 $\mathrm{Pd}$ 的负载量导致时空产率降低, 说明 $\mathrm{Au} / \mathrm{Pd}$ 摩尔比对催化剂的催化活性有很大影响.

除此之外, 以 $3 \mathrm{Au} 1 \mathrm{Pd} / \mathrm{CeO}_{2}$ 催化剂为例, 对催化剂的 稳定性进行了测试(图8). 结果发现, 催化剂循环使用7 次后依然具有良好的催化活性(>79\%), 说明 $\mathrm{AuPd} / \mathrm{CeO}_{2}$ 
双金属催化剂具有良好的稳定性.

另外, 与之前我们报道的 $\mathrm{AuAg} / \mathrm{TiO}_{2}$ (时间 $10 \mathrm{~h}$, 得 率 $82 \%$ ) 催化剂相比, $\mathrm{AuPd} / \mathrm{CeO}_{2}$ 催化剂具有更好的催化 活性, 并且反应过程中催化剂用量较少, 反应条件更温 和. 因此, $\mathrm{AuPd} / \mathrm{CeO}_{2}$ 催化剂是苯甲醇氧化制备苯甲酸 的优良催化剂.

\subsection{AuPd双金属的协同效应}

由于 $\mathrm{Au}$ 基双金属催化剂具有抗烧结能力, 并在许多 反应中表现出高活性和高选择性, 因此得到了广泛关注. 在 $\mathrm{Au}$ 基双金属催化剂中, 由于 $\mathrm{Au}$ 具有很高的电负性, 因 此电子容易从另一种金属向 $\mathrm{Au}$ 上转移, 从而影响 $\mathrm{Au}$ 的 催化性能 ${ }^{[5]}$. Wang 等 ${ }^{[56]}$ 合成了以石墨烯为载体的 $\mathrm{Au}-\mathrm{Pd}$ 催化剂, 该催化剂对甲醇选择性氧化合成甲酸甲酯具有 很好的活性, $\mathrm{Au}$ 和Pd之间的电子转移能够提高催化剂的 催化活性; 并且 $\mathrm{Au}_{2.0}-\mathrm{Pd}_{1.0}$ 石墨烯催化剂中 $\mathrm{Au}$ 和 $\mathrm{Pd}$ 电 子结合能均较低的原因可能是 $\mathrm{Au}$ 和 $\mathrm{Pd}$ 之间电子转移 的结果, 即 $\mathrm{Au}$ 和 $\mathrm{Pd}$ 之间存在协同作用. Wen等 ${ }^{[57]}$ 在研 究 $\mathrm{Cu} / \mathrm{TiO}_{2}-\mathrm{SiO}_{2}$ 催化剂时发现, 由于 $\mathrm{Cu}$ 和 $\mathrm{Ti}$ 之间存在电 子转移, 使得 $\mathrm{Cu} 2 p_{3 / 2}$ 的结合能向低处偏移. Deng课题
组 ${ }^{[58]}$ 在研究Ni-B的表面电子特性时发现, 在Ni-B中B的 结合能向高处移动了大约 $1.1 \mathrm{eV}$, 说明 $\mathrm{B}$ 贡献出电子转 移给合金中的 $\mathrm{Ni}$. 在我们的研究中发现, 不同 $\mathrm{Au} / \mathrm{Pd}$ 摩尔 比的 $\mathrm{AuPd} / \mathrm{CeO}_{2}$ 催化剂中 $\mathrm{Au} 4 f_{7 / 2}$ 和Pd $3 d_{3 / 2}$ 的结合能发 生变化(表3), 也证实了 $\mathrm{Au}$ 和 $\mathrm{Pd}$ 之间电子的相互作用. 由于不同 $\mathrm{Au} / \mathrm{Pd}$ 摩尔比的双金属催化剂的物理化学性 质类似, 因此电子效应是影响 $\mathrm{AuPd} / \mathrm{CeO}_{2}$ 催化剂在苯 甲醇氧化制苯甲酸反应中催化活性的重要因素 ${ }^{[59]}$.

\section{4. 结论}

制备了一系列不同 $\mathrm{Au} / \mathrm{Pd}$ 摩尔比的 $\mathrm{AuPd} / \mathrm{CeO}_{2}$ 催化 剂, 并应用到苯甲醇氧化制苯甲酸钠和苯甲酸反应中, 获得了较好的催化活性. 与单金属催化剂相比, 双金属 催化剂催化性能更好. 这主要归因于 $\mathrm{AuPd} / \mathrm{CeO}_{2}$ 催化剂 中 AuPd合金的形成以及 $\mathrm{Au}$ 和 $\mathrm{Pd}$ 之间的协同作用, 它们 影响了粒径尺寸和电子状态. 当 $\mathrm{Au} / \mathrm{Pd}$ 摩尔比为 $3 / 1$ 时, 催化剂活性最高, 产物得率高达 $92 \%$; 并且反应后催化 剂经过简单处理, 循环使用7次后仍然具有较高的催化 活性. 